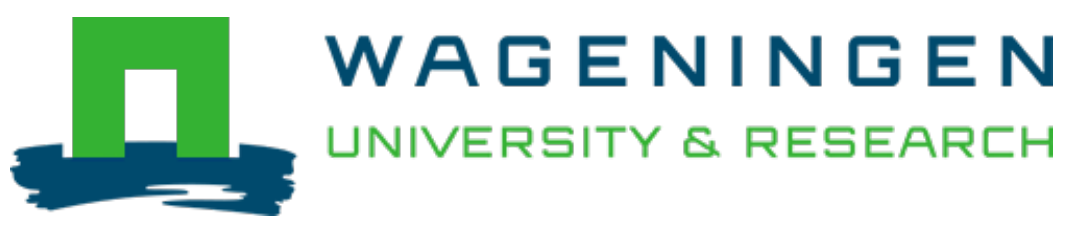

\title{
Environmentally related migration in the digital age: the case of Bangladesh
}

Handbook of Translocal Development and Global Mobilities

Boas, I.J.C.

https://doi.org/10.4337/9781788117425.00010

This publication is made publicly available in the institutional repository of Wageningen University and Research, under the terms of article $25 \mathrm{fa}$ of the Dutch Copyright Act, also known as the Amendment Taverne. This has been done with explicit consent by the author.

Article $25 \mathrm{fa}$ states that the author of a short scientific work funded either wholly or partially by Dutch public funds is entitled to make that work publicly available for no consideration following a reasonable period of time after the work was first published, provided that clear reference is made to the source of the first publication of the work.

This publication is distributed under The Association of Universities in the Netherlands (VSNU) 'Article $25 \mathrm{fa}$ implementation' project. In this project research outputs of researchers employed by Dutch Universities that comply with the legal requirements of Article $25 \mathrm{fa}$ of the Dutch Copyright Act are distributed online and free of cost or other barriers in institutional repositories. Research outputs are distributed six months after their first online publication in the original published version and with proper attribution to the source of the original publication.

You are permitted to download and use the publication for personal purposes. All rights remain with the author(s) and / or copyright owner(s) of this work. Any use of the publication or parts of it other than authorised under article $25 \mathrm{fa}$ of the Dutch Copyright act is prohibited. Wageningen University \& Research and the author(s) of this publication shall not be held responsible or liable for any damages resulting from your (re)use of this publication.

For questions regarding the public availability of this publication please contact openscience.library@wur.nl 


\section{Environmentally related migration in the digital age: the case of Bangladesh \\ Ingrid Boas}

\section{INTRODUCTION}

The nexus between environmental change and human mobility has become one of the key defining elements of global flows in the 21 st century. Environmental change, and climate change in particular, whilst in interaction with other socio-economic factors, may affect people's mobility through the impacts of sea-level rise, storms and droughts. People may be compelled to move to safety in the context of rapid-onset events, such as storms or cyclones. But the decision to move may also develop gradually, as environmental changes develop slowly and worsen step by step, such as sea-level rise or erosion. Environmentally related human mobility, as such, does not manifest itself in one form. Some people may need to migrate for longer periods of time, whereas others may be temporarily displaced for short distances, and still others may not be able to move to safer places at all and may be stuck in dangerous environments (Boas et al. 2018). ${ }^{1}$

Above all, the relation between environmental change and human mobility is not a direct one. Scholarly work on the environment, climate change and migration nexus emphasises the complex and multi-causal relationships in play, demonstrating how this nexus is shaped by a range of social, economic or political factors that inform people's ability to stay or move and aspirations to leave (Black et al. 2011; Morrissey 2013). This nexus is, as such, being shaped (redirected, restricted, regulated, and so on) by other global flows, such as labour markets, climate adaptation funds, information or technological innovations.

Indeed, one of these flows shaping environmentally related human mobility is digital information, exchanged via information and communication technologies (ICTs); in particular, mobile technologies. The ICT revolution has rapidly simplified and expanded options of information exchange from landlines and fax services to more dynamic mobile technologies. Especially in developing countries, mobile technology has provided a boost for connectivity given the lack of landlines (Horst and Miller 2006). It is this interaction of flows that this chapter will address: the nexus between mobile technologies, human mobility and the environment. Yet rather than examining this on a global scale, this chapter will interrogate the interactions of these flows in a case study of environmentally related human mobility in coastal Bangladesh - a place heavily impacted by cyclones, erosion and salination. The resulting human mobility is largely internal and highly varied in terms of being short- or long-distance, temporal or more structural, quick or gradual, depending on 
the environmental impacts and socio-political processes at play. This case therefore has a different context to most of the studies done on the migration-ICT nexus, which often centre on diasporas and transnational movement (for example, special issue by Oiarzabal and Reips 2012; special issue by Leurs and Smets 2018). Furthermore, the focus on Bangladesh also means that this study does not just centre on social media and smart phones, as many studies do. The mobile phone has become widely spread in many developing countries, but the proliferation of smart phones and internet connections is lacking. It is thus still of much interest to examine the impact that access to feature phones (phones without the internet) has (Horst and Miller 2006; Madianou 2015).

In that context, this chapter asks how in this case the social networks and the networking of migrants, and through that their migration trajectories, are being shaped by mobile technologies, including how this informs levels of resilience and sustainable development for those involved. Rather than it necessarily leading to a transformative change in the social networks of these migrants and involved communities, this chapter particularly identifies the change in the content of relations, as in how they are utilised to enable mobility or for mobilising help in a well-coordinated manner. Through the use of mobile technologies, mobility decisions become more reflected on and to an extent less risky, and in this way to an extent positively influence the sustainability of these communities and their mobility practices.

The Bangladesh case study is based on fieldwork that took place between August and December 2017, and centres on two sites heavily affected by environmental impacts from which people were moving away. The first is in the central-south area of Bangladesh, where I studied the southern Upazilas (local political districts) of the island and political district Bhola: Lalmohan and Char Fasson. Here I concentrated on two villages, named Mohammadpur (in Char Fasson) and Patoarir Hat (in Lalmohan), affected by erosion, storms and cyclones, and on village and harbour areas around the local Unions (local districts) Hajarigonj and Jahanpur (in Char Fasson) vulnerable to cyclones but not erosion. The second site is the island and Upazila Kutubdia in the south-east of Bangladesh, where I researched two village areas: one in the local Union Uttar Dhurung in the north, heavily affected by cyclones, daily floods and salination due to a breach in the embankment; and one in the local Union Kayarbil in West Kutubdia, heavily impacted by sea erosion, storms and cyclones. After doing several scoping visits and explorative interviews in these village areas, I selected a set of representative mobility narratives that I researched in more detail. To capture the intersection between the environment, ICT usage and human flows, the research also consisted of tracing the nodes and information exchange central to the selected mobility narratives. This led me to places where people move(d) to, such as neighbouring rural areas or nearby cities like Dhaka, Chittagong and Cox's Bazaar (see Map 3.1 for an overview of the different sites). By following this trail, I gained an in-depth understanding of how the local social networks function and are utilised, of what ties such networks consist, and in particular how this social networking was shaped by mobile technologies. 


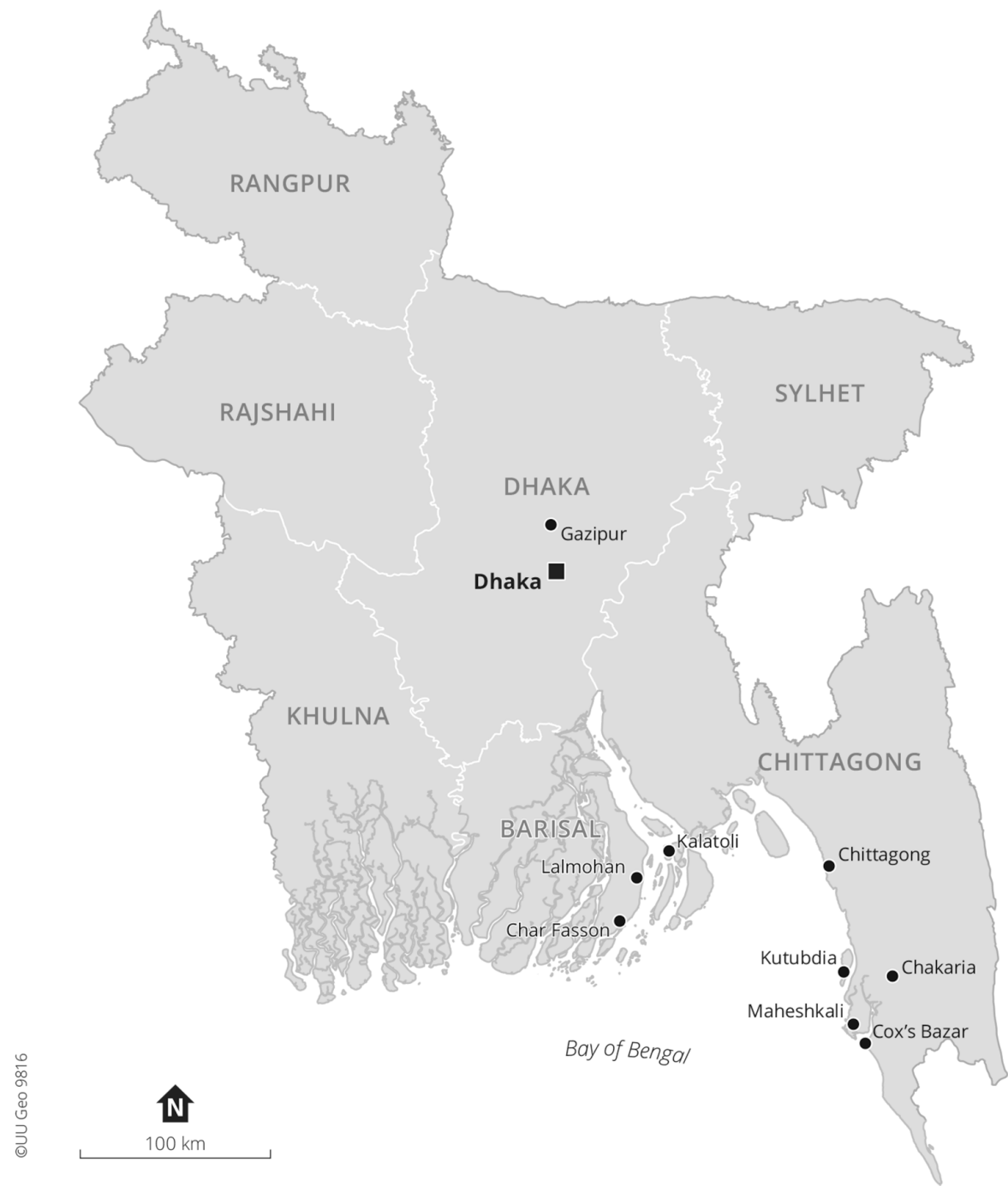

Map $3.1 \quad$ Research area

The chapter is structured as follows. Section 2 provides further background into the growing role of ICTs in Bangladesh, with a focus on mobile technologies, and their implications for migration and social networks. Section 3 provides the case study. Section 4 discusses the findings and concludes. 


\section{ICT-ENABLED NETWORKS IN BANGLADESH}

The introduction of the mobile phone has had a major impact on connectivity in Bangladesh, with many areas not connected via landlines and with low-priced feature phones and mobile phone credit. Mobile cellular phone subscriptions have risen from 1 to 83 per 100 people between 2002 and 2016 (World Bank 2018), with prices for basic feature phones and credit being low, making them widely affordable, combined with the increased use of solar panels in rural areas used for mobile charging. Calling via mobile phone has become a key avenue of communication. People call each other frequently and often just briefly, just to check in. It is not odd to have five missed calls from someone. Texting, on the other hand, is much less popular-partly because still many cannot read and write, and cheaper mobile phones do not support the Bengali characters whilst only higher-educated groups master texting in Latin letters.

Access to phones with the internet is much more limited, however, and network access in rural areas fluctuates (Boas 2017). Facebook is highly popular amongst those having access to the internet on their phones. It is actively used amongst the urban elite and is emerging in rural areas; for instance, amongst the college students. Yet, still many of those I met in affected rural areas in Bangladesh did not have such access during this time of research. There thus remains a divide between those having access to feature phones only and those with smart phones, and between the illiterate who are able to use the calling function of a mobile phone and those who are able to use a variety of ICT functions (Madianou 2015; Boas 2017).

Even so, the ICT revolution is rapidly unfolding, with profound changes in how we communicate and exchange information (Castells 2009), having implications for human mobility and migration (Oiarzabal and Reips 2012; Dekker and Engbersen 2014; Gillespie et al. 2018). This chapter will scrutinise further what these impacts are, how strong they are and how these interact with the social networks and networking of migrants. Building on Granovetter's thesis $(1973,1983)$, it is often assumed that the expansion of weak ties is beneficial for a person's network. By connecting to people or agencies outside the close circle of family and friends, access to information is increased, allowing for more innovation and opportunities to unfold. However, as emphasised by Ryan (2011), Granovetter does not just mean any weak tie being helpful in that regard. They are less valuable when being from similar social locations. They can still be helpful for people to facilitate moving or in getting access to a job, but not so much in the sense of "upward social mobility", and may risk reinforcing social marginalisation (Ryan 2011, 713, 721). It is about "getting by" as opposed to "getting ahead" (Putman 2000, 23, cited in Ryan 2011). In that context, Ryan (2011) proposes to differentiate between horizontal and vertical weak ties: the first is about linking weak ties from similar social locations, and the latter about bridging social distances and providing access to new opportunities and resources, and it can therefore allow someone to progress from their social location.

This begs the question, do ICTs help migrants to more easily connect with vertical weak ties, and what types of contacts are these? Does ICTs help to actually transform social networks in this way, and how does access to ICTs and related changes affect 
mobility decisions? To what extent do existing network dynamics of in/exclusion and unequal access to ICTs prevent that? And if greater access to ICTs does not actively lead to new social networks, what role do ICTs have? How does it impact on the constellation of, and engagement with, strong ties (Larson et al. 2006; De Bruijn 2014) and their resilience to cope with environmental changes?

\section{ICT-ENABLED NETWORKS FOR ENVIRONMENTAL MIGRATION}

The analysis below will demonstrate how social network relations that are not proximate are made relevant to varying forms of environmentally related human mobility through access to mobile technologies. These ICT-enabled networks include networks for micro-coordination in times of emergencies, networks enabling options to leave or to return home, and networks enabling collective action seeking to prevent migration. Most of these networks consist of relatively poor communities, living in highly vulnerable locations to environmental change, without much structural connection to more well-off groups or non-governmental organisations. They live close to the river or the coast, protected by poor embankments, and thus are most vulnerable to cyclones and erosion. Their ICT access is mostly limited to basic feature phones. The exception is the final ICT-enabled network discussed below, being of a more collective nature and led by the more affluent groups in Bangladesh. It is relatively more mixed in terms of ties from different social locations, and includes active smart phone usage.

\section{Micro-coordination in Times of Emergency}

Cyclones come suddenly. Warnings can start early on but may still reach areas late or only few hours before if directions of cyclones change (Lu et al. 2016), or when areas are cut off from proper information flows. In Char Fasson and Kutubdia, affected by some of the more recent cyclones that hit Bangladesh (Char Fasson: Cyclone Mahasen 2013: Kutubdia: Cyclone Roanu 2016 and Cyclone Mora 2017), this resulted in, on the one hand, people staying put to save their belongings or being unable to move to safer areas, and on the other hand, people being forced to leave their homes to take shelter or using their mobility to save livelihood resources several kilometres away. It was about temporary shelter and temporary mobility as people returned to their living areas after the storm had gone and water levels had gone down to fix or rebuild their houses. ${ }^{2}$

When temporarily leaving houses during the storm, quick information exchange was crucial to micro-coordinate coping strategies. The mobile phone is central to enable that (given the mobile towers are still functioning, which they did in the case of Cyclone Mahasen; Lu et al. 2016). As argued by Ling (2000, 112), in introducing the notion of micro-coordination: "the mobile phone allows for a type of very precise adjustment of everyday activities". Responding to a cyclone is no everyday activity, 
but does require very precise and frequent coordination between those affected. Being able to call each other makes it possible to find out quickly what the situation is like some kilometres away, which is crucial to make a decision about the most effective strategy to take. For instance, in Char Fasson many people were reported to be calling each other actively during extreme storms (including Cyclone Mahasen) to coordinate actions to secure and protect the fishing ships at the harbour. ${ }^{3}$ In this way, trade-offs between saving belongings, securing livelihoods and protecting lives by going to the shelter could more easily be made. People could quickly enquire whether it was safe to go to the harbour and to coordinate what help was needed, and to check in with their family whilst at the harbour. This includes a mix of existing strong ties and horizontal weak ties, as this mainly involved exchange amongst families, friends, boat owners and co-workers they already knew and worked with on a daily basis. For example, Zakir, a local fisher, used his mobile phone when at the harbour, to advise other fishers to come whose boats were damaged. ${ }^{4}$ Along similar lines, another local fisher asked a few of his crew members to stay at the ship during the storm to protect it. He constantly communicated with them via mobile phone to know whether all was under control or whether more support was needed. Also these crew members at the ship used their mobile phones to communicate with their families at home or in the shelter to check whether they were safe. ${ }^{5}$

Another example of such micro-coordination in times of emergency is cases where part of the family resided in the shelter whilst another part was elsewhere or unfound. For example, Sahana took shelter with her husband during the cyclone. The next morning her husband returned home to assess the damage, then called her to say all was destroyed. ${ }^{6}$ Women married to fishers also used their mobile phones (or those of others) to trace their husbands if they were still out on sea during a storm. They would try to call him and other fishers on that boat first. If there was no response, they would send someone to the harbour to wait for the husband's return and to report back. ${ }^{7}$

These examples show the central role of the mobile phone in allowing community networks to exchange accurate and up-to-date information for decision-making in times of distress. This is particularly vital as many of the coping strategies involve some form of mobility. Families need to be in different places at the same time to protect their lives and livelihoods, whilst needing to stay in touch to remain up to date on each other's safety.

\section{Enabling Options to Move Away}

Most of the people I met did not move away to another village, region or city on a more permanent basis just because of a cyclone. It can play a role in such movement, but often combined with problems of an economic-political nature and more gradual dynamics of environmental change with unmanaged long-lasting impacts, such as erosion or salination (see also Black et al. 2011). In North Kutubdia, for example, salination has become a key reason for people to move after the embankment was severely broken following several cyclones and storms whilst not being fixed. 
Even under these circumstances, people try to stay as long as they can. Often people do not necessarily want to move away (Adams 2016), nor do they directly know how or what the possibilities are to do so. Over the years an increasing number of people from Bhola and Kutubdia have moved to urban centres, leading to high land and rent prices, with cities being full and slum areas often facing eviction threats to make space for roads, airports and middle-class urban housing. As such, several people I spoke to saw their options as limited. A common strategy is to move more in-land - to move the house bit by bit away from the water. Others move to the side of the embankment, where land is often free (as it is government land). But embankments get increasingly full, plus people may be evicted if the government wants to make changes to the area. That is when the real challenge starts. ${ }^{8}$

Whilst people take it step by step, the need to eventually move does not come as a surprise either. This is where mobile technology comes in - to facilitate the possibility to move should the need arise. The story of Morsheda from North Kutubdia typifies this dynamic. ${ }^{9}$ Morsheda, together with her husband and children, lives in an area that is on a daily basis affected by tidal water, with many houses damaged and agricultural fields destroyed. So far, they have not had the chance to move away. Whilst not an ideal situation, they have managed thus far. Her brother-in-law lives on the mainland facing Kutubdia, where the land is hillier, fluffy and green. She has become very close to her sister-in-law Kadiza (the brother-in-law's wife). She regularly visits them with her children, also during times when the water level is too high for the children to stay home. When being there she actively asks around for opportunities to stay - in a temporary house on someone's land - or about possibilities to get a new piece of land. Currently, Kadiza is also staying in a temporary house on someone else's land, and actively helping to persuade others that Morsheda's family can do the same. Thinking in the long term, she is looking for land they could buy together, although for now they do not have the money to afford it. Morsheda and Kadiza, and also Morsheda's husband and his brother, are in frequent mobile phone contact about this, calling each other frequently. After every severe storm or flood, Morsheda and Kadiza call each other about how "fed up" they are with the situation that is becoming increasingly dangerous for Morsheda's children. ${ }^{10}$

Morsheda's story well reflects that mobile phone technology has been central in maintaining social ties that can facilitate mobility for when the time comes. In this way, the relations are kept warm, and the topic remains urgent, making it a real possibility for Morsheda and her family to move to the same area, even if only temporarily, if the situation demands it. In most such migration narratives traced, including the one by Morsheda, the ties people rely on are strong rather than the weak ones. Most of the people in the areas under study keep in close contact with family members or close neighbours who moved away - if not too far away, they would visit each other, especially during important festivals. This contact frequency has increased with mobile phones, as migrants and those still in places of origin reported calling each other a few times per week. In doing so, as Morsheda's story exemplifies, people make some kind of promise or agreement to help each other out 
should the need arise. Such informal agreements stay active as people can continue to discuss this via phone.

\section{Enabling the Return Home}

Just as mobility is dynamic, so is the Bangladesh landscape, with its highly dynamic river delta where land is gradually disappearing, whilst reappearing in other places (see, for example, Haque and Zaman 1989, also on the associated politics and injustices). ${ }^{11}$ The eroded areas in Bhola have seen numerous embankments, which get broken by erosion and are poorly fixed with temporary sand-based embankments, with many holes remaining. Whether a stronger concrete-based embankment will be made depends on the existence and execution of a tender for a new or improved coastal embankment (and thus political will, available funds and any level of corruption around the execution)..$^{12}$

Once the concrete blocks for the embankment actually start to appear on the shore - which can be after years or even decades of waiting - people get excited. Hope returns. What is interesting to see in such instances is the dynamic of people wanting to move back, to resettle in their places of origin. Mobile phone communication plays a key role in facilitating this drive to return, by sharing photos, via Facebook or Messenger, and spreading the news that something is happening. Nonetheless, not many people actively use Facebook in the area where this embankment is being made (Mohammadpur, Char Fasson). It is an area with low $3 \mathrm{G}$ connectivity, and many inhabitants do not own a smart phone. Simple calling came up more frequently during the interviews as a way in which people were spreading the news and were strategising about the new situation.

A migration narrative representing this dynamic of return is from Babul, from Mohammadpur (Char Fasson). He lives in Dhaka to earn more income after his family experienced land loss due to the erosion and floods from storms, whilst his wife and children stay in Mohammadpur. However, he is gradually moving back to Mohammadpur on a more permanent basis. After years of waiting, the concrete blocks to make a stronger embankment had finally arrived, and new strong sluice gates had been made, making the area more liveable (at least, in the near future). In this new situation, he got the idea to start investing in a family-run sweet-water fish business in his home town, hoping that he could stop working in Dhaka. He has been buying pieces of land to make sweet-water ponds - one is already finished, and he has others in the making. Babul cannot do this alone. He is not the only member of the family who had to work elsewhere who is now wanting to return to make a sweet-water pond fish business. So do his two cousins. This family network of young men is in active mobile phone contact (they call each other every three to four days) to update each other on the situation with the embankment, to discuss progress and problems and doubts about whether it is ever going to get finished, and of course their strategies and plans for their new business. They see it as a serious project and as a way to reunite with their families. ${ }^{13}$ 
Through such active mobile phone contact, part of the family network can maintain their jobs in Dhaka to produce income, whilst the others can focus on the new business in the home town. They can discuss their strategies, ensure a balance in responsibilities and tasks, and coordinate their mobility around this effort (when to go to Dhaka, how long to stay in Dhaka, when to go back). Thus the fact that they can stay in active contact via mobile calls helps to ensure that moving back becomes something planned, organised, coordinated and, most of all, less risky.

\section{Collective Action to Prevent Further Migration}

The diaspora in new locations is not all relatively poor immigrants that had to leave their houses behind. Many are more wealthy and higher educated community members who left to study at the university or to get a better paid job in the city. Particularly in the city of Chittagong, there is a well-connected wealthy diaspora from the island Kutubdia organised via the Kutubdia Association.

The Association aims to better connect the Kutubdia diaspora in Chittagong though limited to the richer and well-educated members of this community. On top of that, it actively tries to help Kutubdia in becoming a safer and more prosperous island. ${ }^{14}$ In that context, the Kutubdia Association has organised a protest action in the form of a human chain in the streets of Chittagong city following Cyclone Mora, which hit Kutubdia in May 2017. It aimed to raise awareness of a broken embankment in Kutubdia that worsens with every cyclone and ongoing erosion, making some areas unliveable. It demanded supervision by the Bangladesh Navy of the reconstruction of the embankment to overcome the ongoing corruption scandals that have led to serious delays and poor-quality construction work. ${ }^{15}$

It was able to attract much attention to the protest and in this way succeeded in making the government promise to take action via the Bangladesh Navy - although the actual implementation remains to be seen. Facebook was a key channel to achieve that. This was led by a university student originally from Kutubdia. He made an event page and a Facebook group specifically for the action, and has actively been posting on the subject. In this way, he argued, "it is easier to reach people, to promote the event. I can even do it from sitting in my home; you do not need to go to all people's houses for impact." ${ }^{16} \mathrm{He}$ was not just any student but a well-connected one, also linked vertically upwards to the political establishment, and in this way could use Facebook quite effectively in reaching a wide audience.

Via Facebook, the human chain action became something people in Kutubdia itself were talking about. To know and see via Facebook that people living in Chittagong were going to the streets to fight for their livelihoods and land resonated. It made them feel connected and less abandoned. At the same time, however, most of the people on Kutubdia seeing such posts and images about the human chain action were those with access to Facebook, meaning young college students in Kutubdia, and especially those groups being somewhat more middle or elite class, such as businessmen and those active in government parties, council members, and so on. These groups also post pictures themselves of flooded areas, damage to the embankment and salinated 
areas to help raise awareness amongst the affluent diaspora in Chittagong having connections to the press, funders and the government.

In that sense, via the photos shared on Facebook, some weak ties - including vertical weak ties - were made, but were limited to those having access to Facebook. Many of the most vulnerable groups living closest to the coast and in the most dangerous zones are often relatively poor and do not have such access. They were less aware of these developments and less involved. In that sense, the enabled network remained relatively elitist and activated horizontal weak ties within similar social circles, or expanded vertically upwards from the more affluent community members and diaspora to more powerful political actors such as members of parliament by sharing Facebook pictures. It did, however, not actively involve the most vulnerable groups, and thus forged no vertical weak ties with the more low-income or marginalised groups. Digital inequality in this way reproduces social hierarchies and strengthens certain support and information networks whilst excluding others from it (see also Madianou 2015).

\section{DISCUSSION AND REFLECTIONS}

To conclude I discuss these findings from two angles. First, I reflect on what the increased access to mobile technologies implies for the social networks and networking of migrants and in what way these are utilised to enable particular mobility practices. Second, I discuss the implications of the intersection between environmental change, human flows and mobile technologies for levels of sustainable development for those involved.

\section{Shifts in Social Networks}

This case study gives little indication of mobile technologies to actively transform the social networks towards a proliferation of vertical weak ties. Instead, existing strong ties - in particular, (extended) family members, close friends and (former) neighbours who people are very closely connected with - remain central for decisions about moving and the stages beyond that. Especially on a village/rural level, there is often a very close interaction with the extended family and neighbours, and that often makes up the basis of the network. When connecting to weak ties, the case study demonstrates these were usually of a horizontal nature.

Part of this can be explained by the particular context of this case, shaping what role the mobile phone plays in ways of connecting and communicating (Horst and Miller 2006). This case study is about migration within a country that has a strong hierarchical culture where it is difficult to rise from one's social location, particularly when being from a lower income group. As such, the digital divide and social inequalities can mutually reinforce each other (Madianou 2015), preventing social networks from becoming more vertical for some. In that context, many of the poorer and less empowered community members I spoke to did not seem to believe in their 
own ability to raise awareness and support for their community; for instance, via collectively using Facebook to spread the word about their situation. Instead they frequently referred to the respected and connected village members or the government as the only avenues from where action can come. Thus whilst social networks "can move" (Schapendonk 2015), there are limits, especially if wanting to connect to more vertical ties (Ryan 2011). Migrants and communities at risk face social and cultural obstacles that are not necessarily easy to overcome.

Despite the limits of ICTs in creating more vertical ties in the social networks of the migrants and communities in the case study of this chapter, the case study results do show that ICTs are creating new roles for geographically distant relations consisting of horizontal ties. These are most often strong ties that people already had, such as friends or family already living in other cities or villages. Via mobile technologies these are kept close and made relevant to facilitate or coordinate someone's mobility - both in the sense of trying to stay, moving away and returning to places of origin. As distance becomes less of an issue, it becomes easier to collectively reflect on, or discuss, mobility strategies and to do so in a very precise and coordinated manner. In this way, connecting with strong ties enables more than a continued "feeling of intimacy" amongst family and friends after having moved away (Dekker and Engbersen 2014 , 407). The role of strong ties, and thus the content of these ties, becomes different as well when people are far apart and staying in different geographical spaces. Through mobile technologies these ties can easily provide up-to-date information about a new place and what is needed to get there. Close friends and (extended) family members already in other places are then vital nodes to connect with to enable mobility in a coordinated fashion and keep the moving process informed by real-time information. Similarly, in the case of the friends and cousins returning back home, the ties in the various locations can easily exchange information about what is needed to organise this most effectively. In that sense, the fact that they are in different locales affords them a particular knowledge, making them key agents of information exchange in facilitating human mobility.

\section{Implications for Sustainable Development}

Has enhanced access to mobile technologies made mobility decisions more resilient to environmental and socio-economic changes, and in what way? Has it contributed to translocal development amongst those involved, and contributed to the United Nations Sustainable Development Goal of making more inclusive, resilient, safe and sustainable human settlements?

As discussed above, in Bangladesh mobile technologies have been proven to better enable people to rely on mobility if the situation demands it. This clearly shows in the experiences of Morsheda, Babul, and of those fishermen micro-coordinating their moves during Cyclone Mahasen. Furthermore, in terms of translocal development, the case of Babul and his cousins typifies how translocal linkages are better enabled through enhanced means of communication to aid and contribute to the exchange of 
ideas, resources, money and environmental information on the state of the embankment, needed to set up their business and enable the return home.

Nonetheless, this translocal development and resilience-building was mainly generated by the migrants and affected communities themselves. The enhanced access to mobile technologies did not generate more vertical ties with non-governmental organisations (NGOs), governments or others. This is partly because of still limited social media usage amongst affected communities and limited attempts from NGOs or other organisations to make such links. But is also relates to the more general character of environmentally related human mobility, being relatively slow and gradual in nature. This is especially so for communities who are affected by river or sea erosion, as erosion does not affect everyone at the same time. Unlike with rapid-onset disasters, people do not leave in large groups who end up in the same shelters or camps, but instead become gradually spread out over the country. In Bangladesh, many areas are affected by gradual river or sea erosion, leading to a highly fragmented yet continuous form of migration: those living closest to the coast have to move first, whilst those living farther away leave a few years or even decades later (Boas et al. 2018). As such, many of these environmentally related migrations do not match the profile of suddenly displaced persons in crisis or disaster situations receiving temporary housing and humanitarian relief. Instead, people who migrate in the context of slow-onset changes miss out on more formal forms of protection. Interviewees from affected areas in Bangladesh stressed that most aid comes after a cyclone, whereas hardly any agency responds to the gradual but devastating impacts of erosion. The slowly creeping problems of erosion often do not make it to the news, making them less attractive for donors. In the absence of formal protection, people are largely on their own, self-governing their situation via their (digital) social networks. The information exchange and support for migration, resettlement, return and inclusive development thus largely originates from, and stays within, the affected community (Boas et al. 2018).

In sum, access to mobile technologies does not necessarily lead to a drastic shift in the network structure that can enhance the resilience and inclusive development of migrants and affected communities through assistance from and exchange with more vertical weak ties (for example, with NGOs or communities in a better socio-economic position). In this case of environmentally related migration in Bangladesh, it instead remains a constellation of mostly strong ties and horizontal weak ties. But there has been an active shift in how these ties, if geographically distant, are used. Precisely because of their distance, translocal connectivity and afforded assets (for example, experience with migration, contacts in destinations, information about places), they become particular helpful to enable mobility, and the decisions around it, in a more coordinated and precise fashion. As a consequence, the decision to move, and the related implications for sustainable development of those involved, becomes more reflected on, better coordinated and in that sense less risky. 


\section{EPILOGUE}

During the Bangladesh Covid-19 lockdown, Kutubdia island (one of the case studies for this chapter) became cut off from the mainland. To prevent travel, the harbour was closed to residents, and no ferries were allowed to transport people to the other side. This had severe impacts for people's incomes. Take the example of Hasan, from Kutubdia island. Hasan lives in a house on the beach side. He used to have a large piece of private land, with trees and space for the cultivation of vegetables. But as the sea slowly ate away the land (as part of erosion processes inherent to the delta), it gradually transformed it into a beach. Today, only a small portion of his land remains. As the sea took his agricultural plot, he turned to drying fish as an alternative livelihood. Yet, COVID-19 and the lockdown made this livelihood impossible, as most of his customers live on the mainland. On top of that, Kutubdia was hit by Cyclone Amphan during the lockdown period, leaving people trapped on the island and seeking safety in crowded cyclone shelters. As Amphan made landfall in another area of Bangladesh, it did not significantly impact Kutubdia. Still, strong winds destroyed Hasan's home. Having already limited income due to the lockdown, he had no other option than to sell his only cow and take a loan to rebuild his house, and to think of other business options. He also reported that the mobile network was weaker than before (it was not clear whether or not this was in any way related to the lockdown), which was complicating his efforts to network and to think of ways ahead.

\section{NOTES}

1. This chapter is a shortened version of Boas 2019, with some new elements. It also contains some paragraphs of Boas et al. 2018.

2. This account is derived from field observations and interviews.

3. Based on interviews, individual and group-based, with fishers, their family members, Red Crescent officers, the head of the dockyard, boat investors and other bystanders.

4. Interview 27 August 2017, Hajarigonj, Char Fasson.

5. Interview with crew members of the ship, 7 October 2017, Jahanpur, Char Fasson.

6. Women's focus group, 23 October 2017, Hajarigonj, Char Fasson.

7. Women's focus group, 23 October 2017, Hajarigonj, Char Fasson.

8. This account is derived from field observations and interviews.

9. Reconstructed from interviews with Morsheda and Kadiza on 19 September 2017, 21 September 2017, 28 September 2017 and 15 November 2017, and from regular visits to their houses and surrounded areas, and regular phone contact with Morsheda.

10. Interview Kadiza, 28 September 2017.

11. See http://aqua-monitor.appspot.com.

12. This account is derived from field observations and interviews.

13. Reconstructed from interviews with Babul and his cousins on 21, 23 and 24 October 2017, 4 November 2017 and 3 December 2017 (in Mohammadpur and Dhaka), and regular visits to Babul's house, the fishpond, and surrounding areas, including the workplaces in Dhaka.

14. Based on interviews with and visits to this association, 22-24 November 2017, Chittagong. 
15. This account is derived from interviews.

16. Interview, 24 November 2017, Chittagong. Quote slightly altered to make it direct and correct English.

\section{REFERENCES}

Adams, H. 2016. "Why populations persist: mobility, place attachment and climate change." Population and Environment, 37(4): 429-448.

Black, R., W. N. Adger, N. W. Arnell, S. Dercon, A. Geddes and D. Thomas. 2011. "The effect of environmental change on human migration." Global Environmental Change, 21: S3-S11.

Boas, I. 2017. "Environmental change and human mobility in the digital age." Geoforum, 85: $153-156$.

Boas, I. 2019. "Social networking in a mobile and digital world: the case of environmentally-related migration in Bangladesh." Journal of Ethnic and Migration Studies, 46(7): 1330-1347. https://doi.org/10.1080/1369183X.2019.1605891.

Boas, I., S. Kloppenburg, J. van Leeuwen and M. Lamers. 2018. "Environmental mobilities: an alternative lens to global environmental governance." Global Environmental Politics, 18(4): 107-126.

Castells, M. 2009. Communication Power. Oxford: Oxford University Press.

Dekker, R., and G. Engbersen. 2014. "How social media transform migrant networks and facilitate migration." Global Networks, 14(4): 401-418.

De Bruijn, M. 2014. "Connecting in mobile communities: an African case study." Media, Culture \& Society, 36(3): 319-335.

Gillespie, M., S. Osseiran and M. Cheesman. 2018. "Syrian refugees and the digital passage to Europe: smartphone infrastructures and affordances." Social Media + Society, 4(1): 1-12. https://doi.org/10.1177\%2F2056305118764440.

Granovetter, M. 1973. "The strength of weak ties." American Journal of Sociology, 78(6): $1360-1380$.

Granovetter, M. 1983. "The strength of weak ties: a network theory revisited." Sociological Theory, 1: 201-233.

Haque, C. E., and M. Q. Zaman. 1989. "Coping with riverbank erosion hazard and displacement in Bangladesh: survival strategies and adjustments." Disasters, 13(4): 300-314.

Horst, H., and D. Miller. 2006. The Cell Phone: An Anthropology of Communication. Oxford: Berg.

Leurs, K., and K. Smets. 2018. "Five questions for digital migration studies: learning from digital connectivity and forced migration in (to) Europe." Social Media + Society, 4(1). doi: $10.1177 / 2056305118764425$.

Ling, R. 2000. "We will be reached': the use of mobile telephony among Norwegian youth." Information Technology \& People, 13(2): 102-120.

Lu, X., D. J. Wrathall, P. R. R. Sundsøy, M. Nadiruzzaman, E. Wetter, A. Iqbal, T. Qureshi, et al. 2016. "Detecting climate adaptation with mobile network data in Bangladesh: anomalies in communication, mobility and consumption patterns during Cyclone Mahasen." Climatic Change, 138 (3-4): 505-519.

Madianou, M. 2015. "Digital inequality and second-order disasters: Social media in the Typhoon Haiyan recovery." Social Media + Society, 1(2): 1-11.

Morrissey, J. 2013. "Understanding the relationship between environmental change and migration: the development of an effects framework based on the case of northern Ethiopia." Global Environmental Change, 23(6): 1501-1510.

Oiarzabal, P. J., and U.-D. Reips. 2012. "Migration and diaspora in the age of information and communication technologies." Journal of Ethnic and Migration Studies, 38(9): 1333-1338. 
Ryan, L. 2011. "Migrants' social networks and weak ties: accessing resources and constructing relationships post $\square$ migration." Sociological Review, 59(4): 707-724.

Schapendonk, J. 2015. "What if networks move? Dynamic social networking in the context of African migration to Europe." Population, Space and Place, 21(8): 809-819.

World Bank. 2018. Data Mobile Cellular Subscriptions. Accessed 27 June 2018. http://data .worldbank.org/indicator/IT.CEL.SETS.P2?end=2015\&start=2002.

\section{SUGGESTED FURTHER READING}

Bettini, G., G. Gioli and R. Felli. 2020. "Clouded skies: How digital technologies could reshape "Loss and Damage" from climate change." Wiley Interdisciplinary Reviews: Climate Change, 11(4). https://doi.org/10.1002/wcc.650.

Black, R., W. N. Adger, N. W. Arnell, S. Dercon, A. Geddes and D. Thomas. 2011. "The effect of environmental change on human migration." Global Environmental Change, 21: S3-S11.

Boas, I., R. Dahm and D. Wrathall. 2020. "Grounding big data on climate-induced human mobility." Geographical Review, 110(1-2): 195-209.

Horst, H., and D. Miller. 2006. The Cell Phone: An Anthropology of Communication. Oxford: Berg.

Ingham, V., M. R. Islam and J. Hicks. 2019. "Adaptive flood mobilities in Bangladesh." Mobilities, 14(2): 158-172.

Madianou, M. 2015. "Digital inequality and second-order disasters: Social media in the Typhoon Haiyan recovery." Social Media + Society, 1(2): 1-11.

Wiegel, H., I. Boas and J. Warner. 2019. "A mobilities perspective on migration in the context of environmental change." Wiley Interdisciplinary Reviews: Climate Change, 10.6 (2019). https://doi.org/10.1002/wcc.610. 